\title{
Tightwads and spendthrifts: An interdisciplinary review
}

\author{
Scott Rick [
}

Ross School of Business, University of Michigan, Ann Arbor, Michigan

Correspondence

Scott Rick, Ross School of Business, University of Michigan, Ann Arbor, MI.

Email: srick@umich.edu

JEL codes: M31, C91, D14, G41
Consumers rely on a "pain of paying" to help deter their spending. While this is beneficial for some consumers, others experience levels of pain that create problems. "Tightwads" experience too much pain when considering spending and therefore spend less than they would ideally like to spend. By contrast, "spendthrifts" experience too little pain and therefore spend more than they would ideally like to spend. Neither are happy with how they handle money. In the decade since the tightwadspendthrift construct was introduced, much has been learned about what it is and is not (e.g., frugality, greed), what contextual factors are likely to reduce its importance, how it plays a role within romantic relationships, and when it might first emerge in childhood. This paper reviews the wide range of interdisciplinary research relevant to the tightwad-spendthrift construct and proposes several directions for new research.

\section{KEYWORDS}

consumer financial decision making, credit cards, financial well-being, judgment and decision making, pain of paying, shopping
Spending decisions can powerfully influence our financial and overall well-being. An unforgettable vacation, an underwhelming gift, or an unaffordable house can all directly or indirectly (e.g., via arguments with a spouse) produce changes in well-being. While it is certainly true that the consequences of some purchase decisions are overstated (e.g., the widely mocked argument that an avocado toast habit is what stands between many millennials and home ownership; Judkis, 2017), it also undoubtedly true that individual and accumulated purchase decisions can be financially and psychologically impactful. Many people who have declared bankruptcy, for example, point to their past spending behavior as a central cause of their financial troubles (Sullivan, 2005). Passing up certain purchase opportunities can also gnaw at us-regrets over our past failures to spend (e.g., on indulgences during vacation) tend to grow over time (Kivetz \& Keinan, 2006).

Given the financial and psychological stakes associated with spending decisions, consumer researchers and many other social scientists have sought to understand the psychol-

This article builds on, significantly extends, and includes a few brief phrases from my previous book chapter on tightwads and spendthrifts (Rick, 2014). ogy of spending decisions. One of the more important insights to emerge from this research is that spending decisions are influenced by a "pain of paying" (Prelec \& Loewenstein, 1998): the more psychological distress consumers experience when contemplating (or making) a purchase, the less likely they are to buy (or buy again). Relying on pain to deter spending helps to explain several phenomena, such as the tendency for payment methods that less vividly remove cash from one's possession (e.g., credit cards) to encourage spending (Raghubir \& Srivastava, 2008).

An important insight regarding the pain of paying is that people differ in their tendency to experience it (Rick, Cryder, \& Loewenstein, 2008). "Tightwads" tend to experience a great deal of pain when contemplating spending and therefore spend less than they would ideally like to spend. "Spendthrifts," by contrast, do not experience enough pain when contemplating spending and therefore spend more than they would ideally like to spend. Research over the past 10 years has demonstrated that one's degree of "tightwaddism" or "spendthriftiness" (i.e., one's location on the tightwad-spendthrift dimension) has important implications for financial well-being, overall well-being, and the quality of interpersonal relationships. In this paper, I review what is known about what tightwaddism is (and is not), factors that 
moderate its influence, some of its nonfinancial consequences, and its possible origins. I also identify some important open questions.

\section{1 | BACKGROUND: THE PAIN OF PAYING}

From a traditional economic perspective, discretionary spending decisions involve a comparison of pleasures. When contemplating whether to buy a good, decision-makers should essentially compare the anticipated pleasure of consuming the good in question and the anticipated pleasure of the best alternative use of the money (e.g., Alchian, 1968). In other words, prices should be interpreted in terms of "opportunity costs" (the pleasures forgone by spending money now instead of later). Descriptively, however, many consumers do not spontaneously consider prices in terms of opportunity costs (Frederick, Novemsky, Wang, Dhar, \& Nowlis, 2009).

In the absence of spontaneous opportunity cost consideration, how do consumers deter their spending? Prelec and Loewenstein (1998) proposed that negative affect experienced in response to considering or actually spending money - a "pain of paying"-is likely to serve an important self-regulatory function. In other words, consumers may avoid spending if the prospect of spending is too painful. Such a process is consistent with the notion that affect can "shift the relevant future payoffs into the current moment" (Frank, 1988, p. 83). This can be helpful (consumers can regulate their spending without having to deliberately consider and weigh opportunity costs), but it can also lead to suboptimal outcomes. For example, even when taking a taxi is affordable and arguably rational (given other demands on one's time), the prospect of anxiously watching a taxi meter tick ever higher may motivate some people to seek cheaper (and slower) forms of transportation.

Importantly, if consumers are weighing anticipatory pleasure and pain when contemplating purchases, then retailers and financial services companies can encourage spending by reducing the pain of paying, without having to increase the objective quality of the purchased good. Credit cards are the classic example of reducing the pain of paying by reducing the vividness of parting with cash, but technological advances are arguably opening up new frontiers in pain reduction. For example, the iPhone $\mathrm{X}$ allows users to "pay with a glance" (glancing at their phone to authorize purchases), and Amazon Go stores feature "just walk out technology" (simply charging users' accounts without any need to physically check out). While such technologies may not instantly change spending behavior, they may train consumers to associate less pain with spending, loosening spending over time.

Since the pain of paying was first proposed by Prelec and Loewenstein (1998), researchers have asked whether it is "real" or simply a helpful metaphor. That is, do consumers actually experience psychological distress when contemplating purchase decisions, or do they simply behave as if they do? The first study to address this question originated in neuroeconomics, a branch of behavioral economics dedicated to understanding the processes underlying economic decisions primarily by using the methods of neuroscience (e.g., Loewenstein, Rick, \& Cohen, 2008). Specifically, Knutson, Rick, Wimmer, Prelec, and Loewenstein (2007) gave participants money and had them make real shopping decisions while having their brains scanned with functional magnetic resonance imaging (fMRI). In each of several trials, participants were first shown an available product (e.g., a DVD box set), then its (discounted) price, and were then asked to indicate (via a small remote control) whether or not they wanted to buy the product for that price. Knutson et al. found that activation in the insula (an area that is reliably active when experiencing distress) in response to prices negatively predicted the likelihood of making a purchase seconds later. Although activation in the insula is involved in some other processes (e.g., taste perception), the evidence was most consistent with the hypothesis that feelings of distress help to deter spending. Using a novel fMRI shopping paradigm, Mazar, Plassmann, Robitaille, and Linder (2017) also observed a negative association between neural evidence of affective distress and the subsequent likelihood of making a purchase. Thus, the available evidence suggests that the pain of paying is indeed a psychological reality.

\section{2 | TIGHTWADS AND SPENDTHRIFTS}

Intuition and anecdotal evidence suggest that people differ in how intensely they experience the pain of paying. Some people seem especially burdened by it, while others seem immune. Rick et al. (2008) reasoned that particularly high or low levels of pain are likely to lead consumers to spend differently than they would ideally like to spend. Specifically, Rick et al. predicted that "tightwads," who experience the pain of paying intensely, may end up spending less than they would ideally like to spend. That is, there may be many instances in which they believe they should buy something, but distress prevents them from acting on that belief. By contrast, "spendthrifts," who experience minimal pain of paying, may end up spending more than they would ideally like to spend. Finally, "unconflicted" consumers, who experience some moderate amount of pain when contemplating spending, may not experience much divergence between their typical spending behavior and their desired spending behavior.

Rick et al. (2008) developed a simple, four-item tightwad-spendthrift (TW-ST) scale to measure these individual differences. The scale items focus on whether consumers have difficulty controlling their spending or difficulty forcing themselves to spend (see Appendix A for full scale). Rick et al. proposed scale score cutoffs to identify 
tightwads, unconflicted consumers, and spendthrifts, though the scale often is, and should be, used as a continuous measure. (Identifying a middle category of "unconflicted" consumers was mainly meant to highlight that both tightwads and spendthrifts are "conflicted," despite their very different approaches to spending.) In samples totaling over 13,000 respondents, Rick et al. found that about $25 \%$ of respondents were classified as tightwads, $15 \%$ were classified as spendthrifts, and $60 \%$ were classified as unconflicted consumers.

TW-ST scores significantly predict debt and savings amounts (Rick et al., 2008), as well as credit scores (Erner, Fox, Chalekian, De La Rosa, \& Trepel, 2016). Importantly, there is no relationship between TW-ST scores and current income (Rick et al., 2008). It is certainly possible that some people became tightwads when money was tight, and then could not shake their well-learned responses to spending when their financial circumstances improved (c.f., Young, 2018). Still, it is not the case that tightwads feel the pain of paying intensely because they cannot currently afford to spend. If anything, given their typical debt and savings profile, tightwads should arguably be the most comfortable making discretionary purchases.

To better understand the nature of the tightwadspendthrift construct, it is helpful to consider what it is not capturing. When first investigating the discriminant validity of the TW-ST scale, Rick et al. (2008) found that the tightwad-spendthrift construct was most closely related to frugality (Lastovicka, Bettencourt, Hughner, \& Kuntze, 1999). Lastovicka et al. (1999, p. 96) define frugality as "a lifestyle trait reflecting disciplined acquisition and resourcefulness in product and service use...in service of achieving longer term goals." Follow-up analyses revealed that frugality is more closely tied to a "pleasure of saving," whereas tightwaddism is more closely tied to a pain of paying (Rick et al., 2008, p. 773). Thus, while tightwaddism and frugality both promote saving, they do so for very different reasons. Rick et al. (2008) demonstrated that the tightwad-spendthrift construct is also related (in the expected directions), but distinct from, constructs such as materialism, self-control, price consciousness, and time preference. Subsequent work has also demonstrated that the tightwad-spendthrift construct is distinct from financial literacy (Fernandes, Lynch, \& Netemeyer, 2014), dispositional greed (Seuntjens, Zeelenberg, van de Ven, \& Breugelmans, 2015), and several other constructs (see Table 1).

While these demonstrations of discriminant validity help to narrow and sharpen our understanding of the tightwadspendthrift construct, recent work on "expense neglect"

TABLE 1 Some correlates of the Tightwad-Spendthrift construct

\begin{tabular}{|c|c|c|c|c|c|}
\hline Measure & Sample item & $\begin{array}{l}\text { Correlation } \\
\text { with TW-ST }\end{array}$ & $N$ & $\begin{array}{l}\text { Source of } \\
\text { measure }\end{array}$ & $\begin{array}{l}\text { Source of } \\
\text { correlation }\end{array}$ \\
\hline Dispositional greed & $\begin{array}{l}\text { As soon as I have acquired something, I start } \\
\text { to think about the next thing I want. }\end{array}$ & .36 & 345 & Seuntjens et al. (2015) & $\begin{array}{l}\text { Seuntjens } \\
\text { et al. (2015) }\end{array}$ \\
\hline Materialism & I like to own things that impress people. & .26 & 257 & Richins (2004) & Rick et al. (2008) \\
\hline $\begin{array}{l}\text { Impatience (time } \\
\text { preference) }\end{array}$ & $\begin{array}{l}\text { Fill in the blank to make } \mathrm{A} \text { and } \mathrm{B} \text { equally } \\
\text { attractive: } \\
\mathrm{A}=\$ 100 \text { immediately, } \mathrm{B}=\$ \_ \text {in } 1 \text { year }\end{array}$ & .12 & 709 & $\begin{array}{l}\text { (many, see Frederick, } \\
\text { Loewenstein, } \\
\text { and O'Donoghue (2002) for } \\
\text { review) }\end{array}$ & Rick et al. (2008) \\
\hline Financial literacy & $\begin{array}{l}\text { Do you think that the following statement is } \\
\text { true or false? "Bonds are normally riskier } \\
\text { than stocks." }\end{array}$ & -.17 & 103 & Fernandes et al. (2014) & $\begin{array}{l}\text { Fernandes } \\
\quad \text { et al. (2014) }\end{array}$ \\
\hline Hyperopia & "Seizing the day" is difficult for me. & -.22 & 164 & Haws and Poynor (2008) & $\begin{array}{l}\text { Haws and Poynor } \\
\text { (2008) }\end{array}$ \\
\hline Lay rationalism & $\begin{array}{l}\text { When making decisions, I like to analyze } \\
\text { financial costs and benefits and resist the } \\
\text { influence of my feelings. }\end{array}$ & -.24 & 185 & $\begin{array}{l}\text { Hsee, Yang, Zheng, } \\
\text { and Wang (2015) }\end{array}$ & Hsee et al. (2015) \\
\hline Self-control & I refuse things that are bad for me. & -.25 & 198 & Tangney et al. (2004) & Rick et al. (2008) \\
\hline $\begin{array}{l}\text { Propensity to plan for } \\
\text { money (short-run) }\end{array}$ & $\begin{array}{l}\text { I set financial goals for the next few days for } \\
\text { what I want to achieve with my money. }\end{array}$ & -.30 & 207 & $\begin{array}{l}\text { Lynch, Netemeyer, Spiller, } \\
\text { and Zammit (2010) }\end{array}$ & $\begin{array}{l}\text { Lynch } \\
\text { et al. (2010) }\end{array}$ \\
\hline $\begin{array}{l}\text { Propensity to plan for } \\
\text { money (long-run) }\end{array}$ & $\begin{array}{l}\text { I set financial goals for the next } 1-2 \text { months } \\
\text { for what I want to achieve with my } \\
\text { money. }\end{array}$ & -.34 & 207 & Lynch et al. (2010) & $\begin{array}{l}\text { Lynch } \\
\quad \text { et al. (2010) }\end{array}$ \\
\hline Delay of gratification & I believe in sacrifice now, enjoy later. & -.36 & 211 & Reyna and Wilhelms (2017) & $\begin{array}{l}\text { Reyna and } \\
\text { Wilhelms } \\
(2017)\end{array}$ \\
\hline Price consciousness & $\begin{array}{l}\text { I will grocery shop at more than one store to } \\
\text { take advantage of low prices. }\end{array}$ & -.40 & 136 & Lichtenstein et al. (1993) & Rick et al. (2008) \\
\hline Frugality & $\begin{array}{l}\text { Making better use of my resources makes me } \\
\text { feel good. }\end{array}$ & -.46 & 1,955 & Lastovicka et al. (1999) & Rick et al. (2008) \\
\hline $\begin{array}{l}\text { Personal saving } \\
\text { orientation }\end{array}$ & $\begin{array}{l}\text { I like to discuss the topic of saving money } \\
\text { with my family and friends. }\end{array}$ & -.54 & 201 & $\begin{array}{l}\text { Dholakia, Tam, Yoon, and } \\
\text { Wong (2016) }\end{array}$ & $\begin{array}{l}\text { Dholakia } \\
\text { et al. (2016) }\end{array}$ \\
\hline
\end{tabular}

Note. All correlations are at least marginally significant. Higher TW-ST scores indicate greater spendthriftiness, meaning that positive correlations indicate factors that are more prevalent among spendthrifts. 
(Berman, Tran, Lynch, \& Zauberman, 2016) potentially broadens our understanding of the construct. Berman et al. find that when consumers forecast their future spare money or "financial slack," they are generally more sensitive to their expectations of future income than to their expectations of future expenses. In other words, consumers generally pay insufficient attention to their own expectations of future expenses when estimating their future financial slack. This is potentially costly, as it could lead people to take on debt that they are unable to pay off later. Importantly, Berman et al. find that while tightwads exhibit some expense neglect, they are significantly less likely to exhibit it than spendthrifts. In fact, spendthrifts place almost no weight on their own expectations of future expenses when forecasting their future financial slack. This suggests that tightwads and spendthrifts differ in the extent to which their expenses are top-of-mind, and that one reason why spendthrifts find spending relatively painless may be that any debt they incur is not interpreted as reducing their future spending potential.

\section{3 | MODERATING FACTORS}

Even though tightwads generally spend less than spendthrifts, there are contexts that reduce the impact of tightwad/ spendthrift differences. Rick et al. (2008) hypothesized that contexts that make spending less painful (e.g., via effective marketing) should reduce tightwad/spendthrift spending differences, primarily by encouraging greater spending among tightwads. Rick et al. (2008) tested this hypothesis by manipulating whether a fee was framed as "small" to influence its perceived magnitude and thus how painful it was to pay. Specifically, Rick et al. ran an experiment that asked participants whether they would be willing to pay either a "\$5 fee" or a "small \$5 fee" for overnight shipping of a desired DVD box set. Unsurprisingly, spendthrifts were significantly more likely than tightwads to pay the fee when it was framed as a " $\$ 5$ fee." However, this tightwad/spendthrift difference disappeared when the same fee was framed as "small." This interaction was entirely driven by tightwads: tightwads were significantly more likely to pay the fee when it was framed as "small" than when it was not, but spendthrifts were completely insensitive to this framing. Similarly, another experiment that framed a massage as either a hedonic experience or an investment in better health found that tightwad/spendthrift differences in willingness to pay for the massage were smallest when it was framed as an investment. As in the other experiment, tightwads were most sensitive to how the massage was framed.

Thomas, Desai, and Seenivasan (2011) further clarified when reductions in the pain of paying are most likely to reduce tightwad/spendthrift spending differences. In the Rick et al. (2008) experiments, the available goods were hedonic (a desired DVD box set and a massage). Thomas et al. (2011, study 4) had participants perform a simulated grocery shopping task in which they decided whether to purchase a series of "virtue" products (e.g., baked beans, fatfree yogurt) and "vice" products (e.g., cookies, soda). (The different types of products had about the same average price.) Participants knew that they would need to pay for their chosen products with either cash or credit. Consistent with the Rick et al. (2008) experiments, for "vice" products, tightwad/spendthrift differences in spending were smallest when participants paid with credit (the relatively less painful payment method). As expected, the interaction was entirely driven by tightwads. Spendthrifts were completely insensitive to payment method. However, for "virtue" products, neither tightwads nor spendthrifts were sensitive to payment method (c.f., Soman, 2003). And, pooling across payment methods, there was little difference in spending between tightwads and spendthrifts for "virtue" products. One interpretation is that for products that people feel good about buying (not necessarily excited, but at least virtuous), there is less pain associated with payment. (Of course, there are certainly instances where paying for "virtue" products would be expected to be painful-for example, if they were outrageously priced or purchased only out of obligation-but that was not the case in the Thomas et al. experiment.) Taken together, the Thomas et al. results suggest that the guilt associated with consuming a particular good contributes to the pain experienced when considering buying it. ${ }^{1}$

Although Thomas et al. (2011) demonstrated that painreducing payment methods can increase tightwads' willingness to buy in some contexts, these results are only relevant outside the lab if tightwads actually embrace payment methods that reduce the pain of paying. Raghubir and Srivastava (2009) raise some doubts about their willingness to do so. They demonstrate that people spend more freely when using smaller money denominations than when using larger denominations (e.g., we spend four $\$ 5$ bills more freely than one $\$ 20$ bill), perhaps because the larger denomination is not placed in an "everyday spending" or "petty cash" mental account (c.f., Shefrin \& Thaler, 1988). Consumers seem to anticipate this pattern-when choosing how to receive money, consumers are, on average, more likely to request larger denominations when entering a context that will tempt them to spend than when entering a context that is not tempting. Importantly, Raghubir and Srivasatava find that this pattern is largely attributable to tightwads. In other words, tightwads are significantly more likely to choose the larger denomination when anticipating a highly tempting context than when anticipating a nontempting context. Spendthrifts' denomination preference, by contrast, is insensitive to what type of context they are about to enter. The results suggest that tightwads seek a payment method that discourages spending, apparently to reduce the likelihood that they actually experience the pain of paying when encountering tempting goods. Of course, consumers do not always have complete control over 
which payment method they use (e.g., at stores that require or ban the use of cash), but when they do, the Raghubir and Srivastava results suggest that tightwads might not embrace the less painful methods.

The Rick et al. (2008) and Thomas et al. (2011) experiments investigated how tightwad/spendthrift spending differences change when the pain of paying is reduced. But how might increasing the pain of paying influence tightwad/ spendthrift spending differences? Here, we would again expect tightwad/spendthrift spending differences to decrease, but now we would expect the movement to come mainly from spendthrifts. In other words, a situation that makes spending especially painful should have less impact on tightwads, who already find many purchase decisions painful. In an experiment that asked participants to (hypothetically) choose between buying a good $\$ 700$ stereo and a better $\$ 1,000$ stereo, Frederick et al. (2009, study 5) manipulated whether or not selecting the cheaper stereo was framed as “leaving you \$300 in cash.” Frederick et al.'s (2009) prior experiments demonstrated that many people do not spontaneously consider opportunity costs (and of course, most brands and retailers do not help customers think about where else their money could be spent). Thus, making salient what is forgone by buying the more expensive stereo should make it especially painful to pay for. Indeed, Frederick et al. (2009) found that tightwad/spendthrift differences were smallest when opportunity costs were made salient. Spendthrifts were significantly less likely to choose the more expensive stereo when opportunity costs were made salient than when they were not salient. Tightwads, by contrast, were not significantly influenced by the salience of opportunity costs. ${ }^{2}$

Taken together, the results of Rick et al. (2008), Thomas et al. (2011), and Frederick et al. (2009) suggest that contexts that influence the pain of paying are likely to influence the size of tightwad/spendthrift spending differences. Contexts that decrease the pain of paying should reduce tightwad/spendthrift spending differences, primarily by changing the behavior of tightwads. Contexts that increase the pain of paying should also reduce tightwad/spendthrift spending differences, but do so primarily by changing the behavior of spendthrifts.

\section{I IMPLICATIONS BEYOND INDIVIDUAL SPENDING DECISIONS}

Tightwads and spendthrifts are presumably conflicted. Both types consistently spend differently than they would ideally like to spend. Rick, Small, and Finkel (2011) investigated whether tightwads and spendthrifts are indeed unhappy being tightwads and spendthrifts. Specifically, Rick et al. had respondents complete the TW-ST scale and then asked them "How happy are you with yourself regarding the spending issues raised above?" and "Do you wish that you could change yourself with respect to the spending issues raised above?" As expected, tightwads and spendthrifts were most likely to indicate that they were unhappy with their typical approach toward spending money (and unconflicted consumers were least likely to indicate that they were unhappy with their typical approach toward spending money).

Rick et al. (2011) examined whether this pattern has implications for our romantic relationships-both who we partner with and the quality of the relationship. Generally speaking, "birds of a feather flock together"-we tend to form relationships with people with similar attitudes, behavioral tendencies, and demographic characteristics (e.g., Watson et al., 2004). In terms of relationship satisfaction, this pattern of "positive assortment" is usually beneficial. Spousal dissimilarity predicts increased marital conflict, which in turn predicts diminished marital well-being (Luo \& Klohnen, 2005). One might therefore expect tightwads to couple with other tightwads and spendthrifts to couple with other spendthrifts. However, other research has questioned whether the typical positive assortment pattern would generalize to disliked aspects of the self. Klohnen and Mendelsohn (1998) argued that complementarity (an "opposites attract" pattern) is likely to be observed for characteristics people dislike in themselves. This reasoning is relevant to the tightwad-spendthrift construct, since both tightwads and spendthrifts are unhappy with that aspect of themselves. Indeed, this reasoning suggests that opposites on the tightwad-spendthrift dimension may be especially attracted to one another.

In three studies, with a total of over 1,500 married respondents, Rick et al. (2011) found consistent evidence that tightwads and spendthrifts are more likely to marry one another than they are to marry someone like themselves (i.e., a significant negative correlation between spouses' TWST scores), a rare instance in which opposites attract. ${ }^{3}$ However, consistent with past research (e.g., Luo \& Klohnen, 2005), the more spouses differed on the tightwad-spendthrift dimension, the more they argued over money, and the less happy they were with their marriage. This held true even controlling for couples' financial outcomes (savings and debt). In other words, even if couples are seemingly comfortable financially, they may still argue over money if spouses disagree about how to spend it. Although the definitive experiment can probably never be conducted (randomly assigning participants to marry one another), the results raise the possibility that tightwads are better off, financially and psychologically, marrying other tightwads. Spendthrifts, by contrast, may face a choice between minimizing conflict (by marrying another spendthrift) and minimizing debt (by marrying a tightwad).

These findings raise questions about how tightwad and spendthrift spouses navigate financial decisions. Many important financial decisions are jointly made by romantic 
partners, and even apparently individual decisions can be influenced by reminders of a partner's preferences (e.g., Simpson, Griskevicius, \& Rothman, 2012). Future research should investigate when tightwad-spendthrift mismatches might be financially beneficial (e.g., if spendthrifts spend more conservatively when accompanied by their tightwad spouse).

\section{I BECOMING A TIGHTWAD OR SPENDTHRIFT}

One of the key open questions surrounding the tightwadspendthrift construct is how it develops in the first place. In other words, how (and when) does someone become a tightwad, unconflicted consumer, or a spendthrift? And is one's location on the tightwad-spendthrift dimension stable across changes in economic conditions and life stage? The answers could have implications for parents, teachers, and anyone else meaningfully involved in the socialization of children.

As a first step toward understanding how one's location on the tightwad-spendthrift dimension develops, Smith, Echelbarger, Gelman, and Rick (2018) examined whether there is any evidence of tightwaddism or spendthriftiness among children. They developed a version of the TW-ST scale that can be completed by 5- to 10-year-olds. Over several trials, children were shown two cartoon creatures who each made statements about their feelings toward spending money ("I feel mostly bad when I spend money" vs. "I feel mostly good when I spend money"), and they were asked to point to the creature whose reaction most closely matches their own typical reaction. Smith et al. found that, like adults, the distribution of child TW-ST scores was skewed toward tightwaddism. Also, comparable to what Rick et al. (2008) observed among adults, older children were somewhat more likely than younger children to be tightwads. Children's TW-ST scores predicted their real spending behavior (when they were given a chance to shop at a laboratory toy store), even when controlling for how much they liked the available toys. Taken together, these early results suggest that feelings resembling tightwaddism and spendthriftiness may emerge as early as age 5. Of course, whether these feelings remain stable over time is an entirely open question.

In a follow-up project, Echelbarger, Smith, Gelman, and Rick are now examining how parents, via conversations with their children about money, transmit their own tightwadspendthrift tendencies. Other projects that investigate (a) how parents' economic and educational characteristics potentially shape their children's tightwad-spendthrift tendencies (c.f., Watts, Duncan, \& Quan, 2018), (b) how observations of parents' spending behavior influence the development of children's tightwad-spendthrift tendencies (c.f., Richins \& Chaplin, 2015), and (c) how tightwad- spendthrift tendencies change over time would also be very valuable.

\section{I CLOSING THOUGHTS AND SOME OPEN QUESTIONS}

In the decade since the tightwad-spendthrift construct was introduced, much has been learned about what it is and is not, what contextual factors are likely to reduce its importance, how it plays a role within romantic relationships, and when it might first emerge in childhood. The studies discussed here raise their own natural follow-up questions-for example, lab experiments demonstrated that tightwads are more sensitive to (unavoidable) marketing appeals that reduce the pain of paying, but will these marketing appeals have the same effect outside the lab, where tightwads might find ways to avoid them? In addition to these natural followup questions, I want to close by highlighting five important open questions that might be less salient based on the research discussed above:

Would tightwads really benefit from spending more money? Tightwads are apparently frustrated with their inability to spend as much or as often as they think they should. This might imply that interventions that encourage tightwads to spend (e.g., reducing pain by requiring that shoppers use credit instead of cash) should increase tightwads' well-being. However, even if interventions can decrease tightwads' pain of paying during purchase decisions, it is unclear whether tightwads would later begin to experience distress from having spent the money (e.g., when their credit card statement arrives). In other words, encouraging tightwads to spend could have the unintended consequence of saddling them with recurring distress.

How does desire influence the pain of paying? A possible alternative explanation for tightwad/spendthrift spending differences could be that spendthrifts simply have greater desire for goods. If spendthrifts generally expect goods to produce great pleasure, there is little reason for distress when they spend. In economic terms, it is particularly easy for spendthrifts to find goods that deliver consumer surplus. However, Rick et al. (2008) and Thomas et al. (2011) find that reducing pain can make tightwads look more like spendthrifts, possibly suggesting that their desire for goods is comparable, and only their pain of paying differs. Still, there may be interesting differences in anticipated enjoyment over time between tightwads and spendthrifts. For example, although consumers generally fail to appreciate how their enjoyment of goods will diminish over time (Wang, Novemsky, \& Dhar, 2009), tightwads might be least likely to make this mistake, which could contribute to their pain of paying.

Do tightwads and spendthrifts differ in their willingness to engage in financial planning? Intuitively, one might expect tightwads to be more likely than spendthrifts to seek 
professional advice about managing their money. After all, tightwads score significantly higher than spendthrifts on Lynch et al.'s (2010) propensity to plan for money scales (see Table 1). However, it is unclear whether this implies tightwads are more willing to pay for financial advice. Tightwads may be "penny-wise and pound-foolish"-while they may avoid many small, potentially wasteful purchases, they may also avoid larger purchases that improve or protect their financial well-being, such as professional financial advice.

Do tightwad/spendthrift differences influence political preferences? Politicians are routinely faced with public decisions about how to spend other people's money. For example, a recent Chicago Tribune headline claimed that "Trump is President Tightwad with his money but a spendthrift with yours" (Huppke, 2017). It would be interesting to examine whether politicians benefit from articulating (and possibly misrepresenting) the extent to which they find spending taxpayers' money painful. In addition, it is worth exploring whether one's tightwad-spendthrift status influences their political preferences. Although an intuitive prediction is that tightwads will prefer candidates who promise to spend conservatively, many tightwads may alternatively believe that government spending is good and may be happy to let someone else do it.

Can we identify tightwads and spendthrifts without using the TW-ST scale? The TW-ST scale is brief, and responses do not appear to be influenced by respondents' selfpresentation concerns, at least when responses are private and anonymous (Rick et al., 2008). However, there are many contexts where administering a private self-report scale would be very inconvenient, if not impossible. Relatedly, to my knowledge, the TW-ST scale has not yet been translated and administered to respondents who do not speak English, and so it is still unclear whether a translated TW-ST scale would measure what it should. Thus, people who might benefit from distinguishing tightwads, unconflicted consumers, and spendthrifts (e.g., marketers, financial service providers, and maybe even politicians) would benefit from new methods for doing so. There have recently been great advances in inferring psychological traits from digital footprints (e.g., Matz \& Netzer, 2017), and such techniques may ultimately help to identify tightwads and spendthrifts "in the wild."

\section{ACKNOWLEDGEMENTS}

The author thanks the FPR Editors for inviting this article and the reviewers for helpful comments.

\section{ENDNOTES}

${ }^{1}$ The results of the Rick et al. and Thomas et al. experiments also serve as a reminder that the pain of paying is not a simple function of price. It is well known, for example, that paying a high absolute price can be almost joyous when it is viewed as a bargain relative to some common or expected price (e.g., Thaler, 1985). Similarly, an outrageously high price on a desired good may lead the consumer to simply ignore the purchase opportunity altogether rather than trigger painful consideration about spending that kind of money.

${ }^{2}$ Using very different experimental procedures, Thunström, Gilbert, and Ritten (2018) found that tightwads were most influenced by the highlighting of opportunity costs, though this conclusion was not robust across different regression models. The results in their control condition, which did not highlight opportunity costs, were also unusual (no significant difference in spending between tightwads and spendthrifts). Despite the equivocal results, Thunström et al.'s experiment highlights that more research is needed into the possibly nuanced relationship between tightwad-spendthrift tendencies and responsiveness to opportunity cost reminders. More broadly, the replicability of all findings reported in this review should be investigated.

${ }^{3}$ In a study of how different household members respond to promotional discounts, Bruno, Cebollada, and Chintagunta (2018) reported conceptually similar results. In particular, they found that, in terms of sensitivity to price promotions, "two individuals living in a household are expected to be as similar as two individuals picked at random from the population" (p. 17).

\section{ORCID}

Scott Rick (D) http://orcid.org/0000-0002-0306-2376

\section{REFERENCES}

Alchian, A. A. (1968). Cost. In International Encyclopedia of the Social Sciences (Vol. 3, pp. 404-415). New York, NY: Macmillan.

Berman, J. Z., Tran, A. T. K., Lynch, J. G., \& Zauberman, G. (2016). Expense neglect in forecasting personal finances. Journal of Marketing Research, 53(4), 535-550.

Bruno, H. A., Cebollada, J., \& Chintagunta, P. K. (2018). Targeting Mr. or Mrs. Smith: Modeling and leveraging intrahousehold heterogeneity in brand choice behavior. Marketing Science, 37(4), 507-684.

Dholakia, U., Tam, L., Yoon, S., \& Wong, N. (2016). The ant and the grasshopper: Understanding personal saving orientation of consumers. Journal of Consumer Research, 43(1), 134-155.

Erner, C., Fox, C. R., Chalekian, J. S., De La Rosa, G., and Trepel, C. (2016). Individual differences in objective and subjective consumer financial well-being (Working Paper).

Fernandes, D., Lynch, J. G., \& Netemeyer, R. G. (2014). Financial literacy, financial education, and downstream financial behaviors. Management Science, 60(8), 1861-1883.

Frank, R. H. (1988). Passions within reason: The strategic role of the emotions. New York, NY: W.W. Norton.

Frederick, S., Loewenstein, G., \& O'Donoghue, T. (2002). Time discounting and time preference: A critical review. Journal of Economic Literature, 40(2), 351-401.

Frederick, S., Novemsky, N., Wang, J., Dhar, R., \& Nowlis, S. (2009). Opportunity cost neglect. Journal of Consumer Research, 36(4), 553-561.

Haws, K. L., \& Poynor, C. (2008). Seize the day! Encouraging indulgence for the hyperopic consumer. Journal of Consumer Research, 35(4), 680-691.

Hsee, C. K., Yang, Y., Zheng, X., \& Wang, H. (2015). Lay rationalism: Individual differences in using reason versus feelings to guide decisions. Journal of Marketing Research, 52(1), 134-146.

Huppke, R. (2017, March 20). Trump is President Tightwad with his money but a spendthrift with yours. The Chicago Tribune.

Judkis, M. (2017, May 15). Don't mess with millennials' avocado toast: The Internet fires back at a millionaire. The Washington Post.

Kivetz, R., \& Keinan, A. (2006). Repenting hyperopia: An analysis of self-control regrets. Journal of Consumer Research, 33(2), 273-282.

Klohnen, E. C., \& Mendelsohn, G. A. (1998). Partner selection for personality characteristics: A couple-centered approach. Personality and Social Psychology Bulletin, 24(3), 268-278.

Knutson, B., Rick, S., Wimmer, E., Prelec, D., \& Loewenstein, G. (2007). Neural predictors of purchases. Neuron, 53, 147-156.

Lastovicka, J. L., Bettencourt, L. A., Hughner, R. S., \& Kuntze, R. J. (1999). Lifestyle of the tight and frugal: Theory and measurement. Journal of Consumer Research, 26(1), 85-98. 
Lichtenstein, D. R., Ridgway, N. M., \& Netemeyer, R. G. (1993). Price perceptions and consumer shopping behavior: A field study. Journal of Marketing Research, 30(2), 234-245.

Loewenstein, G., Rick, S., \& Cohen, J. D. (2008). Neuroeconomics. Annual Review of Psychology, 59, 647-672.

Luo, S., \& Klohnen, E. C. (2005). Assortative mating and marital quality in newlyweds: A couple-centered approach. Journal of Personality and Social Psychology, 88(2), 304-326.

Lynch, J. J., Netemeyer, R. G., Spiller, S. A., \& Zammit, A. (2010). A generalizable scale of propensity to plan: The long and the short of planning for time and for money. Journal of Consumer Research, 37(1), 108-128.

Matz, S., \& Netzer, O. (2017). Using big data as a window into consumers' psychology. Current Opinion in Behavioral Sciences, 18, 7-12.

Mazar, N., Plassmann, H., Robitaille, N., \& Linder, A. (2017). Pain of paying? - A metaphor gone literal: Evidence from neural and behavioral science (INSEAD Working Paper No. 2017/06/MKT).

Prelec, D., \& Loewenstein, G. (1998). The red and the black: Mental accounting of savings and debt. Marketing Science, 17(1), 4-28.

Raghubir, P., \& Srivastava, J. (2008). Monopoly money: The effect of payment coupling and form on spending behavior. Journal of Experimental Psychology: Applied, 14(3), 213-225.

Raghubir, P., \& Srivastava, J. (2009). The denomination effect. Journal of Consumer Research, 36(4), 701-713.

Reyna, V. F., \& Wilhelms, E. A. (2017). The gist of delay of gratification: Understanding and predicting problem behaviors. Journal of Behavioral Decision Making, 30(2), 610-625.

Richins, M. L. (2004). The material values scale: Measurement properties and development of a short form. Journal of Consumer Research, 31(1), 209-219.

Richins, M. L., \& Chaplin, L. N. (2015). Material parenting: How the use of goods in parenting fosters materialism in the next generation. Journal of Consumer Research, 41(6), 1333-1357.

Rick, S. (2014). Tightwads, spendthrifts, and the pain of paying: New insights and open questions. In S. Preston, M. Kringelbach, \& B. Knutson (Eds.), The interdisciplinary science of consumption (pp. 147-161). Cambridge, MA: MIT Press.

Rick, S., Cryder, C. E., \& Loewenstein, G. (2008). Tightwads and spendthrifts. Journal of Consumer Research, 34(6), 767-782.

Rick, S., Small, D. A., \& Finkel, E. J. (2011). Fatal (fiscal) attraction: Spendthrifts and tightwads in marriage. Journal of Marketing Research, 48(2), 228-237.

Seuntjens, T. G., Zeelenberg, M., van de Ven, N., \& Breugelmans, S. M. (2015). Dispositional greed. Journal of Personality and Social Psychology, 108(6), 917-933.
Shefrin, H. M., \& Thaler, R. H. (1988). The behavioral life-cycle hypothesis Economic Inquiry, 26(4), 609-643.

Simpson, J. A., Griskevicius, V., \& Rothman, A. J. (2012). Consumer decisions in relationships. Journal of Consumer Psychology, 22, 304-314.

Smith, C., Echelbarger, M., Gelman, S., \& Rick, S. (2018). Spendthrifts and tightwads in childhood: Feelings about spending predict children's financial decision making. Journal of Behavioral Decision Making, 31(3), 446-460.

Soman, D. (2003). The effect of payment transparency on consumption: Quasi-experiments from the field. Marketing Letters, 14(3), 173-183.

Sullivan, T. A. (2005). Gender differences in accounts of bankruptcy. Saint Louis University Public Law Review, 24, 433-443.

Tangney, J. P., Baumeister, R. F., \& Boone, A. L. (2004). High self-control predicts good adjustment, less pathology, better grades, and interpersonal success. Journal of Personality, 72(2), 271-324.

Thaler, R. H. (1985). Mental accounting and consumer choice. Marketing Science, 4(3), 199-214.

Thomas, M., Desai, K. K., \& Seenivasan, S. (2011). How credit card payments increase unhealthy food purchases: Visceral regulation of vices. Journal of Consumer Research, 38(1), 126-139.

Thunström, L., Gilbert, B., \& Ritten, C. J. (2018). Nudges that hurt those already hurting - distributional and unintended effects of salience nudges. Journal of Economic Behavior and Organization, 153, 267-282.

Wang, J., Novemsky, N., \& Dhar, R. (2009). Anticipating adaptation to products. Journal of Consumer Research, 36(2), 149-159.

Watson, D., Klohnen, E. C., Casillas, A., Simms, E. N., Haig, J., \& Berry, D. S. (2004). Match makers and deal breakers: Analyses of assortative mating in newlywed couples. Journal of Personality, 72(5), 1029-1068.

Watts, T. W., Duncan, G. J., \& Quan, H. (2018). Revisiting the Marshmallow Test: A conceptual replication investigating links between early delay of gratification and later outcomes. Psychological Science, 29(7), 1159-1177.

Young, D. (2018, June 10). I have post-brokeness stress disorder. The New York Times, SR10.

How to cite this article: Rick S. Tightwads and spendthrifts: An interdisciplinary review. Financial Planning Review. 2018;1:e1010. https://doi.org/10. 1002/cfp2.1010 


\section{APPENDIX A : THE TIGHTWAD-SPENDTHRIFT SCALE}

1. Which of the following descriptions fits you better?

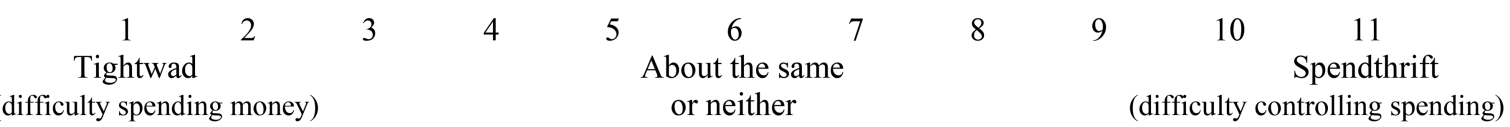

2. Some people have trouble limiting their spending: they often spend money — for example on clothes, meals, vacations, phone calls — when they would do better not to.

Other people have trouble spending money. Perhaps because spending money makes them anxious, they often don't spend money on things they should spend it on.

a. How well does the first description fit you? That is, do you have trouble limiting your spending?

$\begin{array}{lcccr}1 & 2 & 3 & 4 & 5 \\ \text { Never } & \text { Rarely } & \text { Sometimes } & \text { Often } & \text { Always }\end{array}$

b. How well does the second description fit you? That is, do you have trouble spending money?

$\begin{array}{lcccc}1 & 2 & 3 & 4 & 5 \\ \text { Never } & \text { Rarely } & \text { Sometimes } & \text { Often } & \text { Always }\end{array}$

3. Following is a scenario describing the behavior of two shoppers. After reading about each shopper, please answer the question that follows.

Mr. A is accompanying a good friend who is on a shopping spree at a local mall. When they enter a large department store, Mr. A sees that the store has a "one-day-only-sale" where everything is priced $10-60 \%$ off. He realizes he doesn’t need anything, yet can’t resist and ends up spending almost \$100 on stuff.

Mr. B is accompanying a good friend who is on a shopping spree at a local mall. When they enter a large department store, Mr. B sees that the store has a "one-day-only-sale" where everything is priced $10-60 \%$ off. He figures he can get great deals on many items that he needs, yet the thought of spending the money keeps him from buying the stuff.

In terms of your own behavior, who are you more similar to, Mr. A or Mr. B?

1

Mr. A
2

About the same or neither
4 5

Note: Items $2 \mathrm{~b}$ and 3 are reverse-scored. Scale scores range from 4 to 26 . Rick, Cryder, and Loewenstein (2008) proposed that respondents with scores from 4 to 11 can be considered "tightwads," respondents with scores from 12 to 18 can be considered "unconflicted consumers," and respondents with scores from 19 to 26 can be considered "spendthrifts." 